\title{
Association between leptin gene single nucleotide polymorphisms and carcass traits in pigs ${ }^{1}$
}

\author{
Jane de Oliveira Peixoto ${ }^{2 *}$, Danielle Assis de Faria², Priscila Vendramini Silva², Isabela \\ Fonseca², Paulo Sávio Lopes ${ }^{2}$, Simone Eliza Facioni Guimarães ${ }^{2}$ \\ ${ }_{1}^{1}$ Pesquisa financiada pela CAPES, pelo CNPq e pela FAPEMIG. \\ 2 Departamento de Zootecnia, Universidade Federal de Viçosa, CEP: 36570-000, Viçosa, MG, Brasil.
}

\begin{abstract}
It was investigated the association between leptin gene single nucleotide polymorphisms (SNPs) T2411C and $\mathrm{T} 3266 \mathrm{G}$ with carcass traits in F2 pigs obtained by crossing native Brazilian Piau with commercial sows composed of Landrace, Large White and Pietrain breeds. Association analyses were performed using a statistical model that included genotype, sex, and batch as fixed effects, sire and error as random effects. The T2411C SNP was associated with skinless and fatless boston shoulder weight (BSW), backfat thickness at last rib, $6.5 \mathrm{~cm}$ from the midline (P2), skinless and fatless picnic shoulder weight, and sirloin weight (SLW). The T3266G mutation was associated with slaughter age, bacon weight, BSW, midline backfat thickness between last and last but one lumbar vertebra, midline backfat thickness at last rib, P2 and rib weight. Phenotypic associations were also performed by combining genotypes for both SNPs. Associations with P2, carcass yield, total boston shoulder weight, and SLW were observed. The results obtained demonstrate that the SNPs analyzed have potential to be explored as markers for carcass composition in pigs.
\end{abstract}

Key Words: candidate gene, pig genomics, pig production

\section{Associação entre polimorfismos de base única no gene da leptina e características de carcaça em suínos}

\begin{abstract}
RESUMO - Foi investigada a associação entre os polimorfismos de base única (SNPs) T2411C e T3266G da leptina e as características de carcaça em suínos F2 procedentes do cruzamento de machos da raça Piau com matrizes comercias de composição genética Landrace, Large White e Pietrain. As análises de associação foram feitas usando um modelo estatístico que incluía genótipo, sexo e lote como efeitos fixos, e pai e erro como efeitos aleatórios. O SNP T2411C esteve associado ao peso da copa sem pele e sem gordura (BSW), à espessura de gordura subcutânea na altura da última costela a $6,5 \mathrm{~cm}$ da linha média (P2), ao peso da paleta sem pele e sem gordura e ao peso do filezinho (SLW). O SNP T3266G foi associado a idade de abate, peso do bacon, BSW, espessura da gordura subcutânea entre a última e a penúltima vértebra lombar, na linha média, espessura da gordura subcutânea na altura da última costela na linha média, P2 e peso da costela. Os genótipos combinados para ambos os SNP estiveram associados a P2, peso total da copa, rendimento de carcaça e peso do filezinho. Os SNPs analisados têm potencial para ser explorados como marcadores para composição de carcaça em suínos.
\end{abstract}

Palavras-chave: gene candidato, genômica de suínos, produção de suínos

\section{Introduction}

Candidate gene analysis is one of the most common ways to study animal genome, and its main purpose is mapping individual genes related to economic traits. Candidate genes for a given trait are sequenced genes, whose biological action are known and are involved in the development or physiology of a trait (Rothschild \& Soller, 1999). The identification and prediction of individual gene effects is a prerequisite for the marker-assisted selection, but these are not easy questions to solve. The main issue in these methodologies is the quantitative nature of most production traits, whose expression depends on the action and interaction between many genes and between these genes and the environment.

Leptin is a hormone mainly produced by adipose tissue which acts as a hormonal signaling to the brain about the body nutritional status, influencing feeding behavior, metabolism, and energy balance (Campfield et al., 1995). Over the last few years, leptin has been extensively studied 
in domestic animals and due to the importance of leptin in energy metabolism, some reports are available regarding the association between single nucleotide polymorphisms (SNPs) in leptin gene and production traits in pigs and other domestic animals. According to Van der Lende et al. (2005), six different SNPs were included in association analysis in pigs. Jiang \& Gibson (1999) investigated the T3469C SNP in different pig breeds and observed an association with backfat thickness in Large White animals, with the mutated $\mathrm{C}$ variant being associated with higher fatness. Kennes et al. (2001) observed an association between the T3469C SNP and feed intake in Landrace pigs, as well as between the A2845T SNP and age at $100 \mathrm{~kg}$. Frequently, literature regarding the association between SNPs and phenotypic traits are not in total agreement; this can happen due to differences in the origin of the breeds analyzed, or to different lines inside the same breed. Therefore, one should be careful when extrapolating the results obtained from one breed to others since the variation in quantitative traits is the result of the interaction between several genes and the environment.

Due to its physiological functions, Barb et al. (2001) suggested that the leptin gene should be considered as a candidate gene that influences carcass traits in pigs. Therefore, in the present study, it was investigated the association between leptin gene SNPs and carcass traits in a F2 pig population obtained by crossing native Brazilian Piau with commercial sows.

\section{Material and Methods}

The study population was produced by crossing two native Brazilian Piau Boars with 18 commercial white females (Large White $\times$ Landrace $\times$ Pietrain). From F1 generation 12 boars and 54 sows were selected from different litters and crossed to originate the F2 segregating population. The population, the feeding conditions and the carcass evaluation system have been previously described (Carmo et al., 2005). The number of observations, mean, and standard error for the traits analyzed have been described by Band et al. (2005a,b), Faria et al. (2006), and Peixoto et al. (2006).

The SNPs analyzed in the present study have been identified by sequencing the leptin gene (GenBank accession number AY079082) in parental animals of the present crossing. The SNPs are intronic nucleotide changes at positions 2411 (T'!C) and 3266 (T'!G), both originated from Piau sires. These mutations are respectively recognized by the restriction enzymes BamHI and FokI. More details about these SNPs and others found in leptin have been previously described by Peixoto et al. (2006).
DNA extraction and laboratory procedures have already been described (Peixoto et al., 2006). The primer sequences were: BAM-F - gtggggtccagatatccgtt and BAM-R ccaggctaggggtctaatcg that amplify a fragment of $604 \mathrm{bp}$, bearing the T2411C SNP; and FOK-F- tgtgagaaacagacagtcgtgg and FOK-R - tgaggatctgttggtagatcgc, which generates a fragment of $423 \mathrm{bp}$, containing the T3266G SNP. The $20 \mu \mathrm{L}$ PCR mixture was composed of $1 \mathrm{U}$ of Taq DNA polymerase, $0.2 \mathrm{mM}$ of each dNTP, $0.2 \mu \mathrm{M}$ of each primer (forward and reverse), $20 \mathrm{mM}$ Tris- $\mathrm{HCl}, \mathrm{pH} 8.3,2.0 \mathrm{mM} \mathrm{MgCl}_{2}, 50 \mathrm{mM}$ $\mathrm{KCl}$, and $25 \mathrm{ng}$ genomic DNA. The PCR products were then digested with the respective enzymes in a mixture containing $8.0 \mu \mathrm{L}$ of the amplified DNA, $2.5 \mu \mathrm{L}(5 \mathrm{U})$ of enzyme (Invitrogen), $1.5 \mu \mathrm{L}$ of enzyme buffer, and $0.15 \mu \mathrm{L}(2.5 \mathrm{mg} / \mathrm{ml})$ of bovine serum albumin in a final volume of $15.0 \mu \mathrm{L}$ in water. The temperature and digestion time were chosen for each enzyme according to manufacturer instructions.

After digestion, DNA was loaded in $8 \%$ poliacrilamide gel stained with silver nitrate, and the genotypes were classified for each SNP according to the restriction pattern for each SNP. The T2411C SNP genotypes were called AA, $\mathrm{AB}$ or BB for fragments of $604,604 / 495 / 109$ or $495 / 109 \mathrm{bp}$, respectively. For the T3266G SNP, the genotypes were designated as AA, AB or BB for fragments of $423,423 / 243 / 174$ or $243 / 174 \mathrm{bp}$, respectively. In both case, allele B is considered the mutant allele originated from Piau breed, C and $\mathrm{G}$ respectively.

The database consisted of two files: one containing the genotypes of each animal for each SNP and the other the phenotypic measurements of all traits analyzed. Statistical analysis of the association between SNPs and the traits evaluated was performed through the SAS program (SAS, 1998) according to the following model:

$$
\mathrm{y}_{\mathrm{ijklm}}=\mathrm{a}+\mathrm{G}_{\mathrm{i}}+\mathrm{S}_{\mathrm{j}}+\mathrm{GS}_{\mathrm{ij}}+\mathrm{L}_{\mathrm{k}}+\mathrm{p}_{1}+{\left(C_{\text {jilm }}-\bar{C}\right) b}_{b}+\mathrm{e}_{\mathrm{ijklm}},
$$

where $y_{i j k l m}=$ trait observed in animal $\mathrm{m}$ of genotype $\mathrm{i}$, sex $\mathrm{j}$, batch $\mathrm{k}$, and sire $1 ; \mathrm{a}=$ overall mean; $\mathrm{G}_{\mathrm{i}}=$ fixed effect of genotype $\mathrm{i} ; \mathrm{S}_{\mathrm{j}}=$ fixed effect of $\operatorname{sex} \mathrm{j}, \mathrm{j}=1,2$ ( 1 = castrated male, $2=$ female); $\mathrm{GS}_{\mathrm{ij}}=$ interaction between genotype $\mathrm{i}$ and sex $\mathrm{j}$; $\mathrm{L}_{\mathrm{k}}=$ fixed effect of batch $\mathrm{k} ; \mathrm{p}_{1}=$ random effect of sire $\mathrm{l} ; \mathrm{b}=$ linear regression coefficient of trait $\mathrm{y}_{\mathrm{ijk} \mathrm{lm}}$ in relation to the covariate; $\mathrm{C}_{\mathrm{ijklm}}=$ covariate value observed in animal $\mathrm{m}$ of genotype i, sex j, batch $\mathrm{k}$, and sire $1 ; c=$ mean covariate value, and $\mathrm{e}_{\mathrm{ijklm}}=$ random error associated with each observation.

The cooled right half carcass weight was used as covariate for the analysis of carcass and carcass cut traits. The covariances between genetic and environmental effects were considered to be zero. The means obtained for the SNPs were compared by $t$-test. 


\section{Results and Discussion}

For the T2411C and T3266G SNPs, 445 and 369, F2 animals were genotyped, respectively. The allelic and the genotypic frequency have already been described (Peixoto et al., 2006). For both SNPs, the A allele is the non mutated genetic variant, being the mutated variant (B) inherited from the Piau sires.

Table 1 shows the results of the association analysis for the T2411C and T3266G SNPs with carcass and carcass cut traits. The T2411C SNP was significantly $(\mathrm{P}<0.05)$ associated with skinless and fatless picnic shoulder weight (PSW), and sirloin weight (SLW). Regarding skinless and fatless picnic shoulder weight (PSW), higher means $(2.75 \pm 0.04)$ were observed for the non mutated homozygous animals, intermediate means $(2.69 \pm 0.03)$ for heterozygous animals and lower means $(2.62 \pm 0.05)$ for mutated homozygous animals. There was trend of association $(\mathrm{P}<0.10)$ between T2411C SNP with skinless and fatless boston shoulder weight (BSW) and backfat thickness at last rib, $6.5 \mathrm{~cm}$ from the midline (P2). In this case, the mutated allele $(\mathrm{C})$ from the Piau sires was found to be associated with decreased meat deposition and increased fat deposition. The SNP T3266G was associated $(\mathrm{P}<0.05)$ with bacon weight $(\mathrm{BCW})$ and midline backfat thickness between last and last but one lumbar vertebra (LL). There was a trend of association $(\mathrm{P}<0.10)$ with the following traits: slaughter age $(\mathrm{SA})$, skinless and fatless boston shoulder weight (BSW), midline backfat thickness at last rib (LR), backfat thickness at last rib, $6.5 \mathrm{~cm}$ from the midline (P2), and rib weight (RW).

For both SNPs, in this study the mutated allele derived from the Piau sires was found to be associated with decreased meat and increased fat deposition, a finding that agrees with the origin of the mutation in the Piau breed, that has never been selected for meat quality traits and is better known by the lower production performance (Lopes et al., 2002).

Some traits were found to be associated with genetic variants when the combined SNPs genotypes were considered for the association analysis. The genotype combinations and the number of animals per class are described in Table 2. The traits affected by the combined genotypes are presented in Table 3. It could be observed that some traits, in which individual genotypes have effect, are still under the influence of the combined genotypes, like P2 backfat thickness and sirloin weight (SLW). On the other hand, traits that have only been affected by the combined analysis, such as carcass yield (CY) and total boston shoulder weight (TBSW), are correlated to traits affected by the individual genotypes, as shown in Table 4 . Differences between results from individual and combined association analyses could have occurred because the number of genotyped animals was different for each SNPs analyzed.

There are biological evidences that leptin affects important physiological functions in domestic animals (Houseknecht et al., 1998). Statistical association was observed between both SNPs segregating in the F2 population and many traits, suggesting that leptin plays a physiological role in carcass composition traits. Two hypotheses could explain the association between these intronic SNPs and carcass traits. The first hypothesis suggests that the SNP is in linkage disequilibrium with another SNP, which is the causative mutation for the

Table 1 - Least square means (LSM), standard error (se) and carcass cut traits with significant association with T2411C and T3266G leptin SNPs

\begin{tabular}{|c|c|c|c|c|c|}
\hline & & & Genotype AA & Genotype AB & Genotype BB \\
\hline SNP & Trait $^{1}$ & $\mathrm{~F}^{2}$ & $\mathrm{LSM} \pm \mathrm{se}$ & $\mathrm{LSM} \pm \mathrm{se}$ & $\mathrm{LSM} \pm \mathrm{se}$ \\
\hline $\mathrm{T} 2411 \mathrm{C}$ & BSW (kg) & 0.09 & $1.72 \mathrm{a} \pm 0.03$ & $1.68 \mathrm{ab} \pm 0.02$ & $1.65 b \pm 0.03$ \\
\hline $\mathrm{T} 2411 \mathrm{C}$ & P2 (mm) & 0.06 & $16.54 b \pm 0.36$ & $17.42 \mathrm{ab} \pm 0.26$ & $17.55 \mathrm{a} \pm 0.26$ \\
\hline $\mathrm{T} 2411 \mathrm{C}$ & PSW (kg) & 0.05 & $2.75 a \pm 0.04$ & $2.69 \mathrm{ab} \pm 0.03$ & $2.62 b \pm 0.05$ \\
\hline $\mathrm{T} 2411 \mathrm{C}$ & SLW (kg) & 0.01 & $0.22 b \pm 0.01$ & $0.22 b \pm 0.01$ & $0.24 \mathrm{a} \pm 0.01$ \\
\hline T3266G & SA (days) & 0.06 & $149.01 \pm 0.69$ & $146.67 \pm 0.97$ & 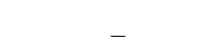 \\
\hline T3266G & BCW (kg) & 0.05 & $2.67 \pm 0.03$ & $2.75 \pm 0.04$ & - \\
\hline T3266G & BSW (kg) & 0.08 & $1.71 \pm 0.02$ & $1.66 \pm 0.03$ & - \\
\hline T3266G & $\mathrm{LL}(\mathrm{mm})$ & 0.04 & $19.41 \pm 0.33$ & $20.65 \pm 0.51$ & - \\
\hline T3266G & $\mathrm{LR}(\mathrm{mm})$ & 0.08 & $27.38 \pm 0.43$ & $28.72 \pm 0.61$ & - \\
\hline T3266G & P2 (mm) & 0.08 & $16.75 \pm 0.27$ & $17.58 \pm 0.42$ & - \\
\hline T3266G & RW (kg) & 0.10 & $1.50 \pm 0.02$ & $1.55 \pm 0.02$ & - \\
\hline
\end{tabular}

${ }^{1}$ BSW - skinless and fatless boston shoulder weight; P2 - backfat thickness at last rib, $6.5 \mathrm{~cm}$ from the midline; PSW - skinless and fatless picnic shoulder weight; SLW - sirloin weight; SA - slaughter age; BCW - bacon weight; LL - midline backfat thickness between last and last but one lumbar vertebra; LR - midline backfat thickness at last rib; RW - rib weight. ${ }^{2}$ Significant differences between genotypes by F-test. Means followed by different letters on the same line are different by t-test $(\mathrm{P}<0.10) . T 3266 \mathrm{G}$ genotype means are different by $\mathrm{F}$ test. 
Table 2 - T2411C and T3266G leptin genotype combination and number of animals per class

\begin{tabular}{cccc}
\hline T2411C genotype & T3266G genotype & Classification* & Number of animals \\
\hline AA & AA & 11 & 64 \\
AA & AB & 12 & 7 \\
AA & BB & 13 & 4 \\
AB & AA & 21 & 52 \\
AB & AB & 22 & 63 \\
AB & BB & 23 & 3 \\
BB & AA & 31 & 5 \\
BB & AB & 32 & 16 \\
BB & BB & 33 & 27 \\
\hline
\end{tabular}

* Classes 12, 13, 23, and 31 were not considered for the statistical analysis due to the small size of each group.

Table 3 - Least square means (LSM) and standard error (se) of significant carcass and carcass cut traits obtained for the combined analysis of T2411C and T3266G SNPs leptin genotypes. Number of animals for each combination is in parenthesis

\begin{tabular}{|c|c|c|c|c|c|c|}
\hline \multirow[b]{2}{*}{ Trait ${ }^{1}$} & \multirow[b]{2}{*}{$\mathrm{F}^{2}$} & \multicolumn{5}{|c|}{ Combined genotype ${ }^{3}$} \\
\hline & & $\begin{array}{c}11(64) \\
\mathrm{LSM} \pm \mathrm{se}\end{array}$ & $\begin{array}{c}21(52) \\
\mathrm{LSM} \pm \mathrm{se}\end{array}$ & $\begin{array}{c}22(63) \\
\mathrm{LSM} \pm \mathrm{se}\end{array}$ & $\begin{array}{c}32(16) \\
\mathrm{LSM} \pm \mathrm{se}\end{array}$ & $\begin{array}{c}33(27) \\
\mathrm{LSM} \pm \text { se }\end{array}$ \\
\hline $\mathrm{P} 2 \quad(\mathrm{~mm})$ & 0.008 & $16.37 \pm 0.57 \mathrm{~b}$ & $16.30 \pm 0.66 \mathrm{~b}$ & $18.05 \pm 0.60 \mathrm{ab}$ & $17.74 \pm 1.04 \mathrm{ab}$ & $19.15 \pm 0.90 \mathrm{a}$ \\
\hline CY (\%) & 0.04 & $82.30 \pm 0.34 \mathrm{a}$ & $81.24 \pm 0.39 \mathrm{ab}$ & $82.15 \pm 0.35 a$ & $80.83 \pm 0.61 b$ & $82.06 \pm 0.52 \mathrm{a}$ \\
\hline TBSW (kg) & 0.05 & $4.89 \pm 0.06 \mathrm{a}$ & $4.96 \pm 0.06 \mathrm{a}$ & $4.83 \pm 0.05 \mathrm{a}$ & $4.67 \pm 0.10 \mathrm{~b}$ & $4.74 \pm 0.09 \mathrm{ab}$ \\
\hline SLW (kg) & 0.02 & $0.22 \pm 0.005 \mathrm{a}$ & $0.20 \pm 0.005 b$ & $0.21 \pm 0.005 \mathrm{ab}$ & $0.22 \pm 0.009 a$ & $0.22 \pm 0.007 \mathrm{a}$ \\
\hline
\end{tabular}

${ }^{1}$ P2 - backfat thickness at last rib, 6,5 cm from the midline; CY - carcass yield; TBSW - total boston shoulder weight; SLW - sirloin weight.

2 Significant differences between genotypes by F-test.

${ }^{3}$ Means followed by different letters on the same line are different $(\mathrm{P}<0.10)$ by t-test.

phenotype variation. According to the USDA-MARC pig linkage map of chromosome 18 (Campbell et al., 2001), the leptin locus (18q13-21) is located close to neuropeptide $\mathrm{Y}$ locus (18q24), a leptin antagonist which is also considered to be a candidate gene that might influence production traits in pigs. The leptin gene may also be linked to other loci with potential biological functions, such as the insulin-like growth factor binding protein 3 (IGFBP3) and growth hormone-releasing hormone receptor (GHRHR) loci, both mapped at SSC18 q24. If this hypothesis is correct, the described leptin SNPs are markers for the real causative mutations. Another possibility is the existence of linkage disequilibrium with SNPs in functional regions inside the leptin gene.

The second hypothesis proposes the existence of falsepositive associations. The statistical model used in the present study assumes that only SNPs, fixed and random effects are influencing trait variation. However, it is known that the phenotypic variation is controlled by several factors, including environment. Another reason for false-positive associations is unbalanced genotype frequency.

The present work presents not only new analysis on backfat thickness measured at many sites along the carcasses, but also the Pearson correlation between them (Table 4). Despite this high correlation between the backfat thickness measures, the SNPs were associated with some but not all of them, for example, the T3266G SNP showed a significant association $(\mathrm{P}<0.05)$ with two fatness measures (bacon weight and midline backfat thickness between last and last but one lumbar vertebra), and the T2411C SNP showed only a trend $(\mathrm{P}<0.10)$ in relation to the $\mathrm{P} 2$ backfat thickness. Moreover, it is interesting that when analyzing the combined genotypes (Table 3 ), the association of the combinations with the $\mathrm{P} 2$ measure is very high $(\mathrm{P}<0.01)$; this could indicate that the use of the combination between both SNPs make a better marker than their genotypes alone. This fact seems to indicate that genomic selection by haplotypes analysis should be preferentially implemented instead of the candidate gene methodology, which aims to mark only one causative mutation.

Peixoto el al. (2006) have tested, in this same population, the association of C798T, T2411C, T3266G, and T3469C leptin SNPs with performance traits. They have found significant associations $(\mathrm{P}<0.05)$ between the SNPs C798T and T3469C with important performance and growth traits such as teat number, weight at different days of age, feed intake, average daily gain, among others. However, for the other SNPs such as T2411C and T3266G SNPs described here, no significant results were found. In the present paper, when the association of the T2411C and T3266G SNPs was done with carcass traits, some trends and even some statistically associated traits could be observed. 


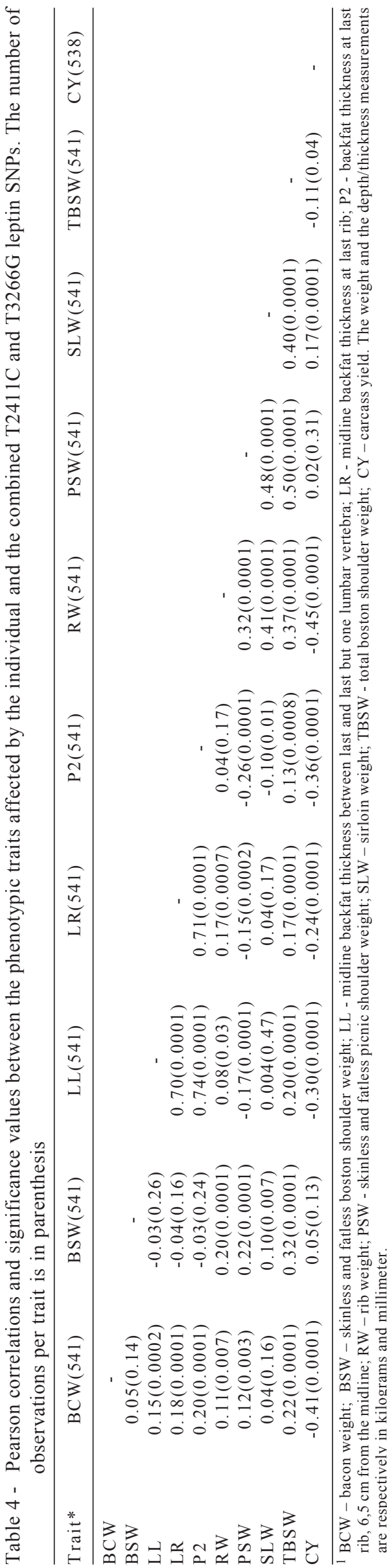

The present study reinforce the results previously described by Peixoto et al. (2006), were it was observed that new allelic variants were identified for the leptin gene in pigs. Moreover, it could be seen in both papers that the leptin variants are associated to many production traits. When the genotypes were analyzed in a combined way, some traits that were not affected by the individual SNPs showed significant statistical association with the combined genotypes. In such cases, correlation between these traits and those affected by the individual genotypes are significant, indicating that the described leptin SNPs are associated to carcass composition in pigs, especially to fat deposition traits. It is possible that the difference in significance between individual and combined analysis was caused by the different number of genotyped animals for each SNP.

\section{Conclusion}

The identified leptin SNPs have shown effects on bacon weight, midline backfat thickness between last and last but one lumbar vertebra, skinless and fatless picnic shoulder weight, and sirloin weight, indicating their potential use in marker-assisted selection programs. However, these associations were detected in an experimental divergent cross and need to be validated in commercial populations before utilization of these markers in breeding programs. It was also observed that animals from non-genetically improved breeds can harbor alleles not described in commercial herds, demonstrating the importance of the conservation of autochthonous genetic resources.

\section{Literature Cited}

BAND, G.O.; GUIMARÃES, S.E.F.; LOPES, P.S. et al. Relationship between the Porcine Stress Syndrome gene and pork quality trait of F2 pigs resulting from divergent crosses. Genetics and Molecular Biology, v.28, n.1, p.88-91, 2005a.

BAND, G.O.; GUIMARÃES, S.E.F.; LOPES, P.S. et al. Relationship between the Porcine Stress Syndrome gene and carcass and performance traits in $\mathrm{F} 2$ pigs resulting from divergent crosses. Genetics and Molecular Biology, v.28, n.1, p.92-96, 2005b.

BARB, C.R.; HAUSMAN, G.J.; HOUSEKNECHT, K.L. Biology of leptin in the pig. Domestic Animal Endocrinology, v.21, n.4, p.297-317, 2001.

CAMPBELL, E.M.G.; FAHRENKRUG, S.C.; VALLET, J.L. et al. An updated linkage and comparative map of porcine chromosome 18. Animal Genetics, v.32, n.6, p.375-379, 2001.

CAMPFIELD, L.A.; SMITH, F.J.; GUISEZ, Y. et al. Recombinant mouse OB protein: evidence for a peripheral signal linking adiposity and central neural networks. Science, v.269, n.5223, p.546-549, 1995 
CARMO, F.M.S.; GUIMARÃES, S.E.F.; LOPES, P.S. et al. Association of MYF5 gene allelic variants with production traits in pigs. Genetics and Molecular Biology, v.28, n.3, p.363-369, 2005.

FARIA, D.A.; GUIMARÃES, S.E.F.; LOPES, P.S. et al. Association between G316A growth hormone polymorphism and economic traits in pigs. Genetics and Molecular Biology, v.29, n.4, p.634-640, 2006.

HOUSEKNECHT, K.L.; BAILE, C.A.; MATTERI, R.L. et al. The biology of leptin: a review. Journal of Animal Science, v.76, n.5, p.1405-1420, 1998.

JIANG, Z.H.; GIBSON, J.P. Genetic polymorphism in the leptin gene and their association with fatness in four pig breeds. Mammalian Genome, v.10, n.2, p.191-193, 1999.

KENNES, Y.M.; MURPHY, B.D.; POTHIER, F. et al. Characterization of swine leptin (LEP) polymorphisms and their association with production traits. Animal Genetics, v.32, n.4, p.215-218, 2001.

LOPES, P.S.; GUIMARÃES, S.E.F.; PIRES, A.V. et al. Results of performance, carcass yield and meat quality traits of F2 crosses between Brazilian native and commercial pigs for QTL mapping.
In: PROCEEDINGS OF WORLD CONGRESS ON GENETICS APPLIED TO LIVESTOCK PRODUCTION, 7., 2002, Montpellier. Anais... Montpellier: 2002. p.155-158.

PEIXOTO, J.O.; GUIMARÃES, S.E.F.; LOPES, P.S. et al. Associations of leptin gene polymorphisms with production traits in pigs. Journal of Animal Breeding and Genetics, v.123, n.6, p.378-383, 2006.

ROHRER, G.A.; KEELE, J.W. Identification of quantitative trait loci affecting carcass composition in swine. I. Fat deposition traits. Journal of Animal Science, v.76, n.9, p.2247-2254, 1998.

ROTHSCHILD, M.F.; SOLLER, M. Candidate gene analysis to detect genes controlling traits of economic importance in domestic livestock. In: SIMPÓSIO INTERNACIONAL DE GENÉTICA E MELhORAMENTO ANIMAL, 1999, Viçosa, MG. Proceedings... Viçosa, MG: 1999. p.219-242.

STATISTICAL ANALYSIS SYSTEM - SAS. User's guide. Cary: Statistical Analysis System, 1998. (CD-ROM).

Van der LENDE, T.; TE PAS, M.F.; VEERKAMP, R.F. et al. Leptin gene polymorphisms and their phenotypic associations. Vitamins and Hormones, v.71, p.373-404, 2005. 